Relations industrielles

Industrial Relations

\title{
Leo McGrady, A Guide to Organizing Unions
}

\section{David McPhillips}

Volume 46, numéro 4, 1991

URI : https://id.erudit.org/iderudit/050728ar

DOI : https://doi.org/10.7202/050728ar

Aller au sommaire du numéro

Éditeur(s)

Département des relations industrielles de l'Université Laval

ISSN

0034-379X (imprimé)

1703-8138 (numérique)

Découvrir la revue

Citer ce compte rendu

McPhillips, D. (1991). Compte rendu de [Leo McGrady, A Guide to Organizing Unions]. Relations industrielles / Industrial Relations, 46(4), 871-872.

https://doi.org/10.7202/050728ar

Tous droits réservés (C) Département des relations industrielles de l'Université Laval, 1991
Ce document est protégé par la loi sur le droit d'auteur. L'utilisation des services d'Érudit (y compris la reproduction) est assujettie à sa politique d'utilisation que vous pouvez consulter en ligne.

https://apropos.erudit.org/fr/usagers/politique-dutilisation/ 
A Guide to Organizing Unions, by Leo McGrady, Markham, Ont., Butterworths, 1989, 151 p., ISBN 0-409-80953-5

This book would be more accurately described as a monograph. Despite having 25 "chapters", there are only 89 actual numbered pages of text. Chapter 16 is only slightly over 100 words long. Therefore, the reader who is expecting a lengthy, detailed discussion of the subject will be disappointed. McGrady states accurately in the Preface, at p. v, that "It is not a complete treatise on that branch of labour law. Rather, in abbreviated from, I have tried to provide a statement of most of the applicable principle and rules. I have included at least one case of references for most propositions".

In my view, the book is also mistitled. The primary content of this book addresses the certification process and rules involved in deciding on an appropriate bargaining unit. Although there is some discussion of other topics such as construction project certification, unfair labour practices, decertification, the duty to bargain in good faith and the Charter of Rights, without any doubt certification is the focal point of the book.

After some very brief paragraphs on the history of certification and the jurisdiction of the labour tribunals, the author turns his attention to the rules governing the certification process. The topics discussed include the status of trade unions, the signing up of members, the definition of employees and employers, the issue of "common employer", access to an employer's property, the build-up principle, the appropriate bargaining unit, time bars, the mechanics of applying for certification, the freeze on working conditions, the withdrawal of certification applications, the certification hearing, the certification vote, raids, and finally, the variance of an existing certification.

The book also contains some excellent reference material including a research guide and bibliography, a model constitution and bylaws, the certification sections of the British Columbia Industrial Relations Act, the forms required under that Act, a list of major Federal and Provincial statutes affecting employees, and a table of concordance for the B.C. Act with the Canada Labour Code and Ontario Labour Relations Act.

The structure of the book is such that McGrady covers each of the topics very briefly. He alerts the reader to the basic principles underlying each of the topics and provides many valuable checklists for an individual who is involved in the certification process. For example, in the section dealing with signing up members, there is an excellent list of basic rules which should be followed by anyone involved in that process. In the same vein, the book contains a "handy check list" of twenty-five questions which will be asked by the Industrial Relations Council in assessing the status of a trade union.

It should also be noted that the book has a heavy British Columbia focus. While many of the principles are applicable in other jurisdictions, the book will be of most value in that province, particularly in terms of the references to statutes and applicable case authorities.

Due to its brevity, the book could simply not contain an exhaustive analysis of this very complicated area. The author does set out very clearly the most basic principles with clarity and exceptionally good organization. However, there are some areas which do require more detail even within the author's goal of avoiding academic analysis. For example, the chapter dealing with the "build-up" principle is oversimplified. Additionally, the issue of variance of a certification in its many forms is extremely complex and the inexperienced reader may be unaware of all the difficulties associated with these topics.

In his Preface, McGrady states that " $(\mathrm{t})$ he book is directed to those who have experience in labour laws and who wish to know the details of that law as it relates to union organizing". 
With respect, I disagree. To those inexperienced in labour law, the book will be too basic as it lacks in-depth discussions of some of the very complicated areas involved in the certification process. The major beneficiaries of this book will be the novice trade union official or even small employer who is faced with a union certification. For these individuals, the book sets out numerous check lists and basic principles in point form which are easily understood.

It would seem that the author himself recognizes this reality, as in the Preface he also states "my initial objective in preparing this guide was to provide an organizing manual that would be on the one hand precise and detailed, and on the other, readily understood by persons organizing for the first time ... I have since revised that original objective and aimed for a more modest publication". It is for the second group identified - namely persons organizing for the first-time - that this book will be an invaluable reference throughout the certification process.

David McPhillips

University of British Columbia

The Origins of Economic Democracy: Profit Sharing and Employee-Shareholding Schemes, by Michael Poole, London, Routledge, 1989, 158 p., ISBN 0-415-02555-9 and The Impact of Economic Democracy: Profit Sharing and Employee Shareholding Schemes, by Michael Poole and Glenville Jenkins, London, Routledge, 1990, 160 p., ISBN 0-415-03587-2

These two companion volumes document the results of the most exhaustive examination of employee profit sharing and shareholding schemes ever conducted in the United Kingdom, or perhaps anywhere, for that matter. The study involved three main phases: (a) telephone interviews with 1,125 British firms in order to ascertain the overall extent of employee profit sharing and employee shareholding (PS/EO) in Britain; (b) detailed interviews with a subset of 303 firms with at least one of these schemes; and (c) extensive case studies of 22 of these firms. As a part of each case study, interviews were conducted with key union and management officials, objective data on company performance was collected, and questionnaires were administered to a sample of employees at each firm. Overall, approximately 2,000 of these questionnaires were collected.

As suggested by the titles of the two books, the results of all this are presented in two parts. First, the factors that cause implementation of profit sharing or share ownership are examined (book 1); and second, the effects of these schemes are identified and discussed (book 2).

In book 1, the development of PS/EO in Britain is first put into historical perspective. Next, possible explanatory frameworks are posited, and Poole argues that the interaction of five sets of factors - government policy, economic infrastructure, managerial strategies, industrial relations, and collective representation - will determine whether or not PS/EO will emerge. The balance of the book consists of chapters devoted to each factor. After a brief concluding chapter, three appendices provide technical details regarding the sample, data analysis, and the questionnaires used.

Overall, Poole concludes that there is no simple explanation for the recent expansion of PS/EO in Britain, although it is clear that the legislative inducements embodied in the 1978, 1980, 1984 Finance Acts have served as a major catalyst. He also finds that it has been the more 